\title{
Farklı Gamların Sazan (Cyprinus carpio L.) Eti Köftelerinin Bazı Özellikleri Üzerine Etkileri
}

\author{
Osman KILINÇÇEKER*, Ali Mücahit KARAHAN \\ Adlyaman Üniversitesi, Teknik Bilimler Meslek Yüksekokulu, Gıda İşleme Bölümü, Kampüs-Adlyaman
}

\begin{abstract}
Öz
Bu çalışmada karagenan, keçiboynuzu ve karboksimetil selüloz gamlarının farklı konsantrasyonlarının çiğ ve kızarmış balık köftelere etkisi araştııılmıştır. Bu gamlar köftelere $\% 0.5, \% 1$ ve $\% 1.5$ oranlarında ilave edilmiştir. Kızarmamış köftelerde 7 gün depolama ile $\mathrm{pH}$, thiobarbütirik asit reaktif madde ve renk özelliklerindeki değişimler belirlenmiştir. Kızarmış köftelerde ise bazı fiziksel, kimyasal ve pişirme özellikleri ile duyusal kalite kriterleri saptanmıştır. Sonuç olarak, gamların ilavesi 1 gün ve 3 gün depolama sonrası $\mathrm{pH}$ değerlerinde düşüşe sebep olurken, gam içeren köftelerin TBARS sayılarının 3. günde ve 7. günde kontrol örneğinden daha düşük oranda oldukları belirlenmiştir. Çiğ örneklerin renk değerlerinde artan depolama sürelerinin daha etkili olduğu, depolama ile bazı örneklerin $L$ değerlerinde ve $a$ değerlerinde azalma, $b$ değerlerinde ise artış olduğu anlaşılmıştır. Ayrıca gam ilavesi kızartılmış sazan eti köftelerinde renk değerlerini geliştirmiş, verim, nem tutma ve bazı duyusal özellikleri artırmıştır. Bazı örneklerde ise yağ emilim oranlarını azaltmıştır. Bütün sonuçlara göre, köfte hazırlamada en avantajlı uygulamanın \%1 karagenan veya \%1.5 keçiboynuzu gamı ilave etmek olduğu gözlenmiştir.
\end{abstract}

Anahtar kelimeler: Karagenan, Keçiboynuzu, Karboksimetil selüloz, Sazan (Cyprinus carpio L.), Balık köfte kalitesi.

\section{The Effects of Different Gums on Some Properties of Mirror Carp (Cyprinus carpio L.) Meatballs}

\begin{abstract}
In this study, effects of treatments with different rations of carrageenan, locust bean, and carboxymethylcellulose gums on raw and fried fish meatballs were investigated. These gums were added at levels of $0.5 \%, 1 \%$, and $1.5 \%$ in samples. pH, TBARS and colour properties of raw samples determined during cold storage for seven days. Also, some physical, chemical and cooking properties and sensory quality criteria's of fried meatballs were revealed. As a result, addition of gums decreased $\mathrm{pH}$ values after 1 day and 3 day storage whereas it was determined TBARS values of samples with gums were lower than control sample after 3 day and 7 day storage. Increasing of storage times had more effect on the colour values of raw samples. $L$ values and $a$ values of some raw samples decreased whereas $b$ values increased during cold storage. However, the use of gums improved the colour values and increased the yields, moisture retentions and some sensory properties of fried meatballs, generally. Also, it decreased the fat absorption of some samples. According to results, most advantageous treatments for fish meatballs production were $1 \%$ level of carrageenan and $1.5 \%$ level of locust bean gums, respectively.
\end{abstract}

Keywords: Carrageenan, Locust bean, Carboxymethylcellulose, Mirror Carp (Cyprinus carpio L.), Fish meatball quality.

\footnotetext{
* Sorumlu yazar: okilincceker@adiyaman.edu.tr

Geliş Tarihi: 27.06.2018, Kabul Tarihi: 31.10.2018

Bu çalışma Uluslararası Mühendislik ve Teknoloji Sempozyumu (2018, Batman)'da sunulmuş ve özet olarak basılmıştır.
} 


\section{Giriş}

Sağlıklı yaşam bilinci ve gıda teknolojisinin gelişimi ile birlikte insanlardaki beslenme tarzı da değişmektedir. Özellikle obezite ve kalp-damar hastalıklarındaki artışın etkisiyle yağ oranı azaltılmış gidalara eğilim artmaktadır $[1,2]$.

Benzer nedenlerle gida üreticileri çeşitli doğal ve yapay katkı maddelerini kullanarak insanlara farklı alternatifler sunmaya çalışmaktadırlar. Ürün yelpazesini genişleterek tüketici tercihini etkilemeyi hedeflemektedirler. Ayrıca bu alternatifleri ortaya çıkarırken son ürünün fiziksel, kimyasal ve duyusal özelliklerini de iyileştirmeyi, hatta raf ömrünü uzatarak ürün kayıplarını minimuma düşürmeyi hedeflemektedirler [3, 4].

$\mathrm{Bu}$ uygulamalara çeşitli koruyucuların, stabilizörlerin, renk maddeleri veya tekstür düzenleyicilerin kullanımı örnek olarak verilebilirken, en çok araştırılan materyallerden birisi de gamlardır. Özellikle hidrokolloid karakter gösteren gamlar birçok farklı kaynaktan elde edilebilirler. Gamlar düşük oranda kullanım ile gida yapısındaki suyu bağlama, jel oluşturma ve jelatinize olma özelliği sergilerler. Bu özelliklerinden dolayı özellikle kızartma gibi pişirme işlemi uygulanan gıdalarda yapıda tutulan su miktarını artırarak, emilen yağ oranını azaltabilmekte, alınan kalori değerini düşürebilmektedirler. Ayrıca, ürünün rengini ve raf ömrünü artırdıkları, bazılarının ise diğer gamlar ile birlikte kullanımları durumunda bu etkilerini daha fazla ortaya çıkardıkları ile ilgili bulgular mevcuttur. Bahsedilen özelliklerine ek olarak gamların genel olarak renk değerlerinin düşük olması, tat ve kokularının olmaması diğer avantajları arasında sayılabilir $[2,5,6]$.

Benzer çalışmalara, Ulu [1]'nun karagenan $(\mathrm{KG})$ ve guar gamı ile hazırladığı pişmiş köftelerde yağ oranını azalttığ 1 ve tekstürü iyileştirdiği, Demirci ve arkadaşları [5]'nın et köftelerde gam kullanımı ile ham ve pişmiş örneklerde bazı özellikleri olumlu şekilde etkiledikleri denemeler örnek olarak verilebilir. Ayrıca Kılınççeker [2]'in farklı gamlar ile hazırladığı tavuk köftelerde ham örneklerdeki pH ve TBARS artışını yavaşlattığı, kızarmış örneklerde ise renk, nem tutma ve duyusal özellikleri iyileştirdiği uygulamalar da örnek olarak gösterilebilir.

Fakat literatürdeki araştırmalara bakıldığında özellikle kolay bozulabilen ve işlemesi zor olan balık etlerinde gamların kullanımı ile ilgili çalışmaların yetersiz olduğu gözlenmiştir. Yemek sektöründe hızla yer alan balık etlerini farklı bileşeneler ile zenginleştirerek kalite niteliklerinde görülebilen problemleri çözmenin ve daha sağlıklı ürünler geliştirmenin hem gıda hem de balıkçlık sektörü için önemli olduğu anlaşılmıştır. Hızlı bozulma özelliğine sahip olan bu et türünün ömrünü özellikle gam kullanımı ile artırarak daha fazla ekonomik kazanç sağlanabileceği birçok çalışmada ortaya koyulmuştur $[7,8]$.

Bahsedilenler doğrultusunda bu çalışmada $\mathrm{KG}$, keçiboynuzu $(\mathrm{KB})$ ve karboksimetil selüloz (KMS) gamlarını aynalı sazan (Cyprinus carpio L.) etine farklı oranlarda ilave ederek ürünün bazı kalite parametrelerini iyileştirmek ve raf ömrünü artırmak amaçlanmıştır. KG kırmızı deniz yosunundan elde edilen, viskozite sağlama ve jelleşme özelliği yüksek olan bir gamdır. KB keçiboynuzu ağacının tohumlarından elde edilen ve düşük konsantrasyonlarda yüksek viskozite sağlayan bir gam iken, KMS bir selüloz türevi olup gida sektöründe en yaygın kullanılan gam türlerinden birisidir. Bu maddelerin her birinin farklı özelliğe sahip olmasından dolayı köfte üretiminde kullanılacak gam türü ve gam miktarının önemli olduğu düşünülmüş, bu çalışma yapılarak normal sazan eti köftelerine göre daha üstün kalite parametrelerine sahip ve raf ömrü daha uzun olan sazan eti köfteleri geliştirmek istenmiştir.

\section{Materyal ve Metot}

Çalışmada kullanılan karagenan (KG), keçiboynuzu (KB) ve karboksimetilselüloz (KMS) gamları Kimbiotek Kim. Mad. San. Tic. A.Ş. (İstanbul) firmasından temin edilmiştir. Taze sazan (Cyprinus carpio L.) eti ve diğer katkılar Adıyaman'daki yerel firmalardan satın alınmıştır. Balıklar içi ve derisi temizlendikten sonra kaynar suda 3 d haşlanmış, kılçıları çıkarılmış ve kıyma makinasının (Tefal, Le Hachoir 1500, France) 3'lük aynasında kıyılmıştır. Daha sonra; \%93.5 kıyılmış et, \%5 galeta unu ile $\% 1.5$ tuz birleştirilip $10 \mathrm{~d}$ yoğurularak ön karışım hazırlanmıştır. Bu ön karışımlardan alarak \%0.5, \%1 ve \%1.5 seviyelerinde gam ilavesi ile asıl örnekler hazırlanmış, son olarak, yaklaşık $19.5 \mathrm{~g}$ ağırlı̆̆ında ve $31 \mathrm{~mm}$ çapında yuvarlak halinde köfteler üretilmiştir. Daha sonra hazırlanan sazan eti köfteleri iki gruba ayrılmıştır. İlk grupta, plastik tabaklara her bir örnek için dört adet konulup strech film ile sarılan ham örnekler $4{ }^{\circ} \mathrm{C}$ 'de depolanıp 1, 3 ve 7 . günlerde $\mathrm{pH}$, thiobarbütirik asit reaktif madde (TBARS) ve 
renk analizlerine tabi tutulmuşlardır. İkinci grupta ise, her bir örnek için dört köftenin kızartma öncesi ağırlıkları ve çapları alınmıştır. Sonra, ayçiçek yağı (Yudum) kullanarak sıcaklığı ayarlanabilen bir mini fritöz (Tefal, Moulinex Minuto AF100316, France) içerisinde $170{ }^{\circ} \mathrm{C}$ 'de $6 \mathrm{~d}$ kızartılmış, tekrar ağırlıkları ve çapları ölçülmüsstür. Aynı örneklerde kızartma öncesi ve sonrası nem, yağ oranları da tespit edilirken, her bir örnek için 6 köfte daha alınarak benzer sıcaklık ve sürede kızartma yapılmış ve renk ölçümleri ile duyusal analizlerde kullanılmıştır. Yapılan çalışma ile ilgili uygulanan işlemler Şekil 1'de özetlenmiştir.

\section{1. pH ve TBARS analizleri}

Üretim sonrası depolanan köftelerin $\mathrm{pH}$ analizleri bir $\mathrm{pH}$ metre (Orion 3-star, Thermo Fisher Scientific, waltham, MA) kullanımı sayesinde yapılmıştır. Homojen karıştırılmış köftelerden $10 \mathrm{~g}$ alınarak $100 \mathrm{ml}$ saf su ile $5 \mathrm{~d}$ karıştırılmış ve $\mathrm{pH}$ değerleri tespit edilmiştir [9]. Yağ oksidasyonunu tespit etmek için yapılan TBARS analizi ise Tarladgis ve arkadaşları [10]'na göre belirlenmiştir. Bunun için $10 \mathrm{~g}$ örnek alınarak bir behere koyulmuş, üzerine $50 \mathrm{ml}$ saf su eklenmiştir. İyice karıştırmayı takiben $47.5 \mathrm{ml}$ saf su daha ilave edilerek Kjeldahl balonuna aktarılmıştır. Balon içerisine 4 N'lik HCl'den (merck) $2.5 \mathrm{ml}$ ve 2 damla silikon yağı ilave ettikten sonra distilasyon ünitesine bağlanmıştır. Yaklaşık $50 \mathrm{ml}$ distilat elde edilince $5 \mathrm{ml}$ distilat alınıp cam tüplere aktarılmış ve $5 \mathrm{ml}$ TBA reaktifi (merck) ilave edilmiştir. Tüpler 35 d kaynar su banyosunda bekletilerek oda sıcaklığına soğutulmuş ve bu çözeltilerin, spektrofotometrede (UV-160 A, Shimadzu, Tokyo), $538 \mathrm{~nm}$ dalga boyunda, köre karş1 absorbansları okunmuştur. Bulunan değerler 7.8 ile çarpılarak TBA sonuçları mg MDA/kg örnek olarak ortaya çıkarılmıştır.

\subsection{Renk analizleri}

Ham ve kızarmış örneklerde saptanan renk ölçümleri her bir örnek için dört farklı köftenin iki farklı noktasından olacak şekilde gerçekleştirilmiştir. Ölçümde Minalto CR-400 (Osaka) marka kolorimetre kullanılmıştır. Öncelikle cihaz standart olarak kalibre edilmiş ve sonuçlar CIELAB sistemine göre $L$ (açıklık-koyuluk), $a$ (kırmızılık-yeşillik) ve $b$ (sarılık-mavilik) değerleri şeklinde ifade edilmiştir.

\subsection{Kızartma verimi ve çap azalmasının belirlenmesi}

$\mathrm{Bu}$ değerler kızartma öncesi ve sonrası ağırlık ve çaplarının ölçülmesi ile belirlenen verilerin aşağıdaki formüllerde kullanımı ile hesaplanmıştır [2].

$$
\begin{aligned}
& \text { Kızartma verimi (\%) }=\frac{\text { Kızarmış kōfte ağırlığ }}{\text { çiğ kōfte ağırlığı }} \times 100
\end{aligned}
$$

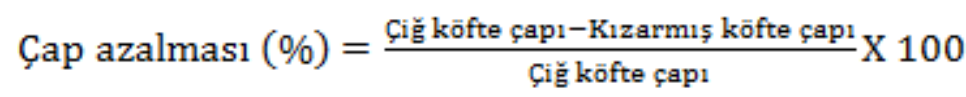

\subsection{Nem tutma ve yăg emilim değerlerinin belirlenmesi}

$\mathrm{Bu}$ değerlerin hesaplanmasında kullanılan nem oranları örneklerin $105^{\circ} \mathrm{C}$ 'de etüvde kurutulması, yağ oranları sokshelet ekstraksiyon metodu sayesinde hegzan kullanımı ile bulunmuştur [11]. Sazan (Cyprinus carpio L.) eti köftelerinin nem tutma ve yağ emilim oranları ise aşağıdaki formüllere göre hesaplanmıştır [2].

$$
\begin{aligned}
& \text { Nem tutma }(\%)=\frac{\text { Kızarmıs̆ kōftedeki nem }(\%)}{\text { Çĭ̄ kōfttedeki nem }(\%)} x \text { verím } \\
& \text { Yağ emilim }(\%)=\text { kızarmış köftedeki yağ }(\%)-\text { çĭğ köftedeki yağ }(\%)
\end{aligned}
$$




\subsection{Duyusal analizler}

Duyusal analizler için Gıda İşleme Bölümü öğrencisi olan 5 kız ve 5 erkek öğrenci olacak şekilde toplam 10 kişi seçilmiştir. Panelistler sigara içmeyen ve duyusal bir problem yaratacak hastalığ olmayan kişilerden oluşturulmuş, ayrıca puanlama öncesi kısa bir eğitime tabi tutulmuşlardır. Puanlama yöntemi olarak hoşlanma derecesine bağlı değerlendirmenin yapıldığı hedonik skala kullanılmıştır. Köfteler kızartmayı takiben yaklaşık $2 \mathrm{~d}$ sonra servis edilmiş ve kişilerden hoşlanma derecelerine bağlı olarak 19 arasında puan vermeleri istenmiştir. Ayrıca her örneğin tadımından sonra panelistler ağızlarını su ile çalkalamışlardır [12].

\section{6. İstatistiksel analizler}

Yapılan çalışma faktöriyel deneme desenine göre üç faktörün (karagenen, keçiboynuzu, karboksimetil selüloz) üç seviyesi (\%0.5, \%1 ve \%1.5) olacak şekilde dizayn edilmiştir. Ayrıca iki tekerrür ve üç paralel olarak gerçekleştirilmiştir. Bulunan sonuçlara varyans analizi uygulanmış, önemli çıkan faktörler $p<0.05$ düzeyinde Duncan çoklu karşılaştırma testine tabi tutulmuşlardır. (SPSS, CHICAGO, IL, USA).

\section{Bulgular ve Tartışma}

\subsection{Depolanan pişmemiş sazan eti köftelerinin pH, TBARS ve renk değerleri}

Pişmemiş beyaz et ve ürünlerinde depolama sırasında oluşan en önemli bozulma reaksiyonları azotlu maddelerde ve yağ asitlerinde meydana gelenlerdir. Çeşitli enzimatik ve mikrobiyolojik faaliyetler sonucu oluşan amonyak gibi ürünler $\mathrm{pH}$ değerini yükseltirken, özellikle doymamış yağ asitlerinin hava oksijeni ile etkileşimi sonucu oluşan aldehit ve keton gibi ürünler ise TBA reaktif madde değerini artırırlar. Bu iki değerin artışıla oluşan kokuşma ve acılaşma bozulmanın belirtisi olup raf ömrünün tespitinde önemli kriterlerdir $[13,14]$. Bu nedenle özellikle bu iki analiz çalışmada uygulanarak sonuçları Tablo 1'de sunulmuştur. Tablodan da anlaşılabileceği gibi gam türü kızarmamış örneklerin pH değeri üzerinde 3. günde ve 7. günde önemli etkiye sahip olurken, gam konsantrasyonu bütün depolama zamanlarında etkili olmuştur $(p<0.05)$. Ayrıca depolama sürelerinin $\mathrm{pH}$ değişimlerindeki etkisi de önemli çıkmıştır $(p<0.01)$. Gam türünün TBARS üzerindeki etkisi 1 gün ve 7 gün depolamada önemli iken, gam konsantrasyonu bütün depolama dönemlerinde etkili olmuştur ( $p<0.05$ ). Depolamanın etkisine bakıldığında ise $\mathrm{pH}$ 'daki gibi genel olarak depolama sürelerinin TBARS değişimlerinde önemli etkiye sahip olduğu anlaşılmıştır ( $p<0.01$, Tablo 1). İlk gün gam içeren örneklerin tamamı kontrolden düşük $\mathrm{pH}$ değerlerine sahip iken, bu değerler giderek artmıştır. 7 gün depolama sonunda en düşük pH'ya KB ve KMS içeren köfteler sahip olmuştur. Konsantrasyon artış1 sadece 3. günde KMS içeren köftelerde düzensiz bir değişime sebep olmuştur. Son depolama döneminde en düşük pH değeri 6.89 olarak \%1 KMS içeren örnekte ortaya çıkmıştır. pH değerlerinin tersine TBARS ortalamaları ilk gün genel olarak bütün örneklerde kontrol örneğinden yüksek çıkarken, 7 gün depolama sonunda gam içeren bütün sazan eti köftelerinin TBARS değeri kontrolden düşük çıkmıştır. Gam konsantrasyonu artış1 1. günde KG ve KMS ile hazırlanan sazan eti köftelerinin TBARS değerlerinde artışa sebep olmuş, diğer dönemlerde ise kontrol dışındaki örnekler arasında etkiye sahip olmadığı anlaşılmıştır $(p>0.05)$. Depolama işleminde süre artışı TBARS değerlerinde düzensiz bir değişime sebep olurken, son döneme bakıldığında en düşük TBARS sonuçlarının $\% 1.5 \mathrm{KG}$ ve $\% 1.5 \mathrm{~KB}$ ile hazırlanan örneklerde $0.24 \mathrm{mg} \mathrm{MDA} / \mathrm{kg}$ ve $0.25 \mathrm{mg}$ MDA/kg olarak ortaya çıtı̆̆ 1 görülebilmektedir. Depolama süresince $\mathrm{pH}$ değerlerindeki artış proteolitik enzimlerin azotlu bileşikleri parçalamasından dolayıdır. Oluşan bazik karakterli ikincil ürünler $\mathrm{pH}$ değerlerini yükseltirler. $\mathrm{pH}$ 'da görülebilen düzensiz değişimler ise bazik karakterli bu maddelerin oksidasyon esnasında oluşan aldehit ve keton gibi maddelerle verdiği reaksiyonlar sonucudur. $\mathrm{Bu}$ reaksiyonlar sonucu hem $\mathrm{pH}$ hem de TBARS değerlerinde düzensiz değişimler görülebilmektedir [15].

Sonuçlarımız Cadun ve arkadaşları [16]'nın buğday ve elma lifi katarak hazırladıkları balık köfteleri çiğ olarak soğukta depoladıklarında $\mathrm{pH}$ değerlerinin muamelelere göre değiştiğini, 5. günde bu değerin 6.21-7.12 arasında olduğunu belirledikleri çalışma ile benzerlik göstermektedir. Ayrıca Demirci ve arkadaşları [5] tarafından sığır etine farklı gamları katarak yaptıkları çalışmada ham ve pişmiş örneklerde $\mathrm{pH}$ değerlerini 6.7-6.9 arasında saptadıkları sonuçlara uygunluk gösterirken, bütün depolama dönemlerindeki pH'lar Varlık ve arkadaşları [12] ile Gülyavuz ve Ünlüsayın [17] tarafından, türüne 
bağlı olarak değişebileceği vurgulanarak, balık etleri için 6.8-7 arası olarak verilen sınır değerlere yakın oldukları anlaşılmıştır.

TBARS değerlerinin 1. günde bazı örneklerde kontrolden yüksek çıkması gamların oluşturduğu sert yapının yüzeysel çatlakları artırması sonucu oksijenin etkisinin artmasına bağlanabilir. Ayrıca ilk gündeki konsantrasyon artışına bağlı TBARS değerlerindeki yükselmeler de benzer sebebe bağlanabilir. KB ile hazırlanan örneklerdeki düzensiz TBA artışı, $\mathrm{pH}$ sonuçlarında da vurgulandığı gibi, bozulma ile oluşan metabolitlerin birbiri ile gösterdiği tepkimeler nedeniyledir denilebilir. Çalışmamızdaki TBARS sonuçları Kılınççeker [2] tarafından tavuk köftelere farklı gamların ilavesi ile yapılan çalışmada gam tipinin, gam konsantrasyonunun ve soğukta depolama sürelerinin TBARS değerlerini etkilediğini vurguladığ çalışma ile benzerlik göstermektedir. Bahsedilen çalışmada 10. gün sonunda TBARS değerleri $0.22-0.36 \mathrm{mg} \mathrm{MDA} / \mathrm{kg}$ arasında tespit edilmiş olup, bizim sonuçlarımızla yakın değerlerde oldukları anlaşılmıştır. Bununla birlikte, Cadun ve arkadaşları [16] tarafından buğday ve elma lifi ile hazırlanan ve soğukta depolanan balık köftelerde 5. günde 0.58-0.81 mg MDA/kg arası olarak belirlenen sonuçlardan daha düşük değerlere sahip oldukları görülmüştür. Depolamanın son günü olan 7. gün sonunda Göğüş ve Kolsarıcı [18] ve Varlık ve arkadaşları [12] tarafindan balık etleri için maksimum tüketim sınırı olarak verilen 7-8 mg MDA/kg'dan daha az oldukları anlaşılmış, hatta Varlık ve arkadaşları [12] tarafından çok iyi kalite su ürünleri için $3 \mathrm{mg}$ MDA $/ \mathrm{kg}$ 'dan daha az olmalı denilen TBARS değerlerine sahip oldukları tespit edilmiştir.

Bu tarz gıdaların çiğ olarak satışı esnasında tüketiciyi etkileyen önemli niteliklerinden birisi de renktir. Çiğ örneklerdeki renk değerleri kullanılan katkı maddelerinden etkilenebileceği gibi depolama esnasında oluşan bozulmalar nedeniyle de değişim gösterebilmektedirler [2]. Bu nedenle ürün geliştirme çalışmalarında renk ölçümlerinin yapılmasında fayda olduğu düşünülmektedir. Tablo 1'e bakıldığı zaman $L$ değerleri üzerinde sadece 7 . günde $\mathrm{KB}$ ve KMS gamlarının avantajlı olduğu, konsantrasyon artışının 3. günde KMS için avantajlı olduğu, 7. günde ise $K G$ ve $K B$ içeren örnekler için düzensiz bir değişime sebep olduğu anlaşılmıştır. Depolama süresi $L$ değerleri üzerinde çoğunlukla etkisiz olurken ( $p>0.05$ ), bazı örneklerde düşüşe sebep olmuştur. Depolamanın son günü olan 7. günde en yüksek $L$ değerleri $54.69,54.58$ ve 54.21 olarak \%0.5, \%1 ve \%1.5 oranında KMS ile hazırlanan sazan eti köftelerde ölçülmüştür. Gam türleri $a$ değerleri üzerinde önemli bir etki sergilememiştir $(p>0.05)$. Gam konsantrasyonu artışı ilk gün KB ve KMS içeren sazan eti köftelerinin $a$ değerlerinde düzensiz bir düşüşe 7. günde ise sadece KMS içeren örneklerin $a$ değerlerinde kontrol örneğine göre hafif bir azalmaya sebep olmuştur. Genel olarak, depolama zamanının artış $a$ değerlerinde düşüşe sebep olurken, son depolama döneminde en yüksek $a$ değerleri 4.24 ve 4.38 olarak kontrol ve $\% 1.5$ oranında KG içeren örneklerde ortaya çıkmıştır (Tablo 1). Ham sazan eti köftelerin $b$ değerlerine bakıldığında; bazı örneklerde KB ve KMS kullanımının avantajlı olduğu söylenebilir. Gam konsantrasyonu artışı 1. günde KMS içeren örneklerdeki, 7. gün de ise KB içeren örneklerdeki $b$ değerlerini düzensiz bir şekilde artırıcı etkiye sahip olmuştur. Depolama süreleri $\% 0.5$ ve $\% 1 \mathrm{~KB}$ içeren örneklerin $b$ değerlerinde düzensiz bir değişime sebep olurken, diğer örneklerde etki göstermemiştir. Depolama sonunda en yüksek $b$ değerleri özellikle 10.50, 10.51 ve 10.72 olarak KMS ile hazırlanan sazan eti köftelerin yüzeylerinde saptanmışır (Tablo 1). Çalışmamıza benzer şekilde, Kılınççeker [2] tarafından farklı gamlar ile hazırlanan tavuk köftelerde çiğ örneklerin renk değerlerinin gam tipi, gam miktarı ve depolama zamanlarından etkilendiği, gam ilavesi ile depolama süresince renk değerlerinin iyileştirilebileceği vurgulanmıştır. Ayrıca, Demirci ve arkadaşları [5]'nın farklı gamlar ile hazırladığı et köftelerin çiğ örneklerinde gam türünün $L$ değerlerini, $a$ değerlerini ve $b$ değerlerini etkilediği bulunmuştur. Çiğ örneklerdeki $L$ değerleri 35.40-41.20, $a$ değerleri 4.2-5.8 ve $b$ değerleri ise 10.24-12.7 aralığında ölçülmüştür. Köfte içerisindeki gam miktarı arttıkça $a$ değerlerinin azaldığı, $b$ değerlerinin ise düzensiz bir değişim gösterdiği vurgulanmıştır. Bu değişimlerin gamların doğal renk maddesi olan karotenoid gibi bileşenlere bağlı olduğu belirtilmiştir. Bizim çalışmamızdaki $L$ değerleri bu değerlerden yüksek bulunurken, $a$ değerlerinin ve $b$ değerlerinin son dönemlerde daha düşük olduğu anlaşılmıştır. Başka bir çalışmada da; Cava ve arkadaşları [19] tarafından çeşitli lifler ile hazırlanan tavuk eti ürünlerinin çiğ örneklerinde renk değerlerinin lif tipine ve miktarına bağlı olarak değiştiği saptanmıştır. Bahsedilen çalışmada $L$ değerleri 47.7-67.8, $a$ değerleri $0.6-13.5$ ve $b$ değerleri 5.7-33.7 aralıklarında belirlenmiş olup, bizim çalışmamızdaki değerlerin çoğunlukla bu sonuçlar ile benzeştiği anlaşılmıştır. Bu iki çalışmaya kıyasla 
bazı örneklerimizde farklılıkların olması çalışmalarda kullanılan malzemelerin doğal renk maddelerinin farklılığına bağlanmaktadır.

Tablo 1. Gam türü ve konsantrasyonunun farklı depolama sürelerinde çiğ sazan eti köftelerinin pH, TBARS ve renk değerleri üzerine etkileri

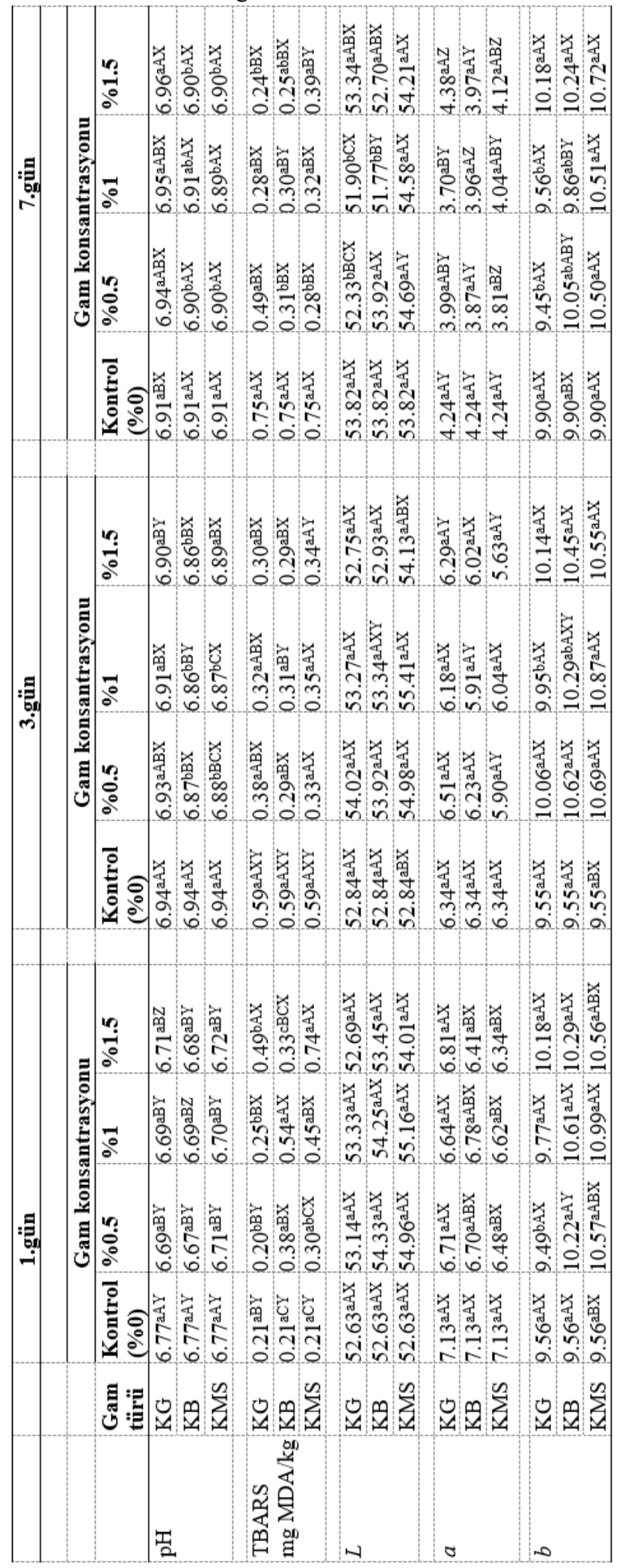

${ }^{\text {a-c }}$ Her bir sütun içerisinde, her bir konsantrasyon için gamlar arasındaki farklılığı belirtmektedir $(p<0.05)$. A-C Her bir satır içerisinde, her bir depolama süresi için, gam konsantrasyonları arası farklılığı belirtmektedir $(p<0.05)$. ${ }^{\mathrm{X}-\mathrm{Z}} \mathrm{Her}$ bir satır içerisinde, her bir gam konsantrasyonunun depolamaya bağlı farklılı̆ını belirtmektedir $(p<0.05)$. 


\subsection{Kızarmış sazan eti köftelerinin renk değerleri}

Balık ve tavuk etinden hazırlanan ürünlerde kızartma sonrası oluşan renk değerleri çiğ örneklerdeki gibi göze çarpan ilk kalite kriterlerindendir. Çoğunlukla, bu tarz gıdalarda kızartma ile oluşan altın-sarısı renk arzu edilen bir durumdur [15]. Çalışmada kızartma sonrası elde edilen renk değerlerine ait sonuçlar Tablo 2'de verilmiştir. Tabloya göre, $L$ değerleri üzerinde gam türü $\% 1$ ve $\% 1.5$ düzeyinde etkili iken, gam konsantrasyonu KG ve KMS ile hazırlanan köftelerde önemli etkiye sahip olmuştur $(p<0.05)$. En yüksek $L$ değerlerini 42.68 ve 42.70 olarak \%1 ve \%1.5 KB ile hazırlanan örnekler verirken, KG ve KMS gamının eklenmesi $L$ değerlerini düşürmüştür. Örneklerin $a$ değerlerine bakıldığında, gam türünün etkisi $\% 1$ ve $\% 1.5$ seviyelerinde önemli çıkmış, konsantrasyon artışı da $a$ değerlerini etkilemiştir ( $p<$ 0.05). Özellikle karagenan eklenmesi $a$ değerini artırmıştır. Sonuçlara göre, en yüksek $a$ değerleri 11.05 ve 11.45 olarak $\% 1$ ve $\% 1.5 \mathrm{KG}$ ile hazırlanan köftelerde ölçülmüştür. $b$ değerleri üzerinde gam türü sadece \%1 seviyesinde etkiye sahip olmuştur $(p<0.05)$. Diğer muamelelerde ve konsantrasyon artışında sonuçların etkilenmediği anlaşılırken ( $p>0.05$ ), en yüksek $b$ değeri 17.36 ve 17.45 olarak \%1 ve \%1.5 KB ile hazırlanıp kızartılan sazan eti köftelerde ortaya çıkmışırı (Tablo 2).

Benzer olarak Demirci ve arkadaşları [5] tarafindan farklı gamlar ile hazırlanan ve pişirilen et köftelerde $L$ değerinin gam türünden etkilendiği, $a$ değerlerinin ve $b$ değerlerinin ise etkilenmediği saptanmıştır. Çalışmada gam konsantrasyonu artışının $L$ değerlerini ve $b$ değerlerini arttırdığı, $a$ değerlerini azalttığ gözlenmiştir. Yasarlar ve arkadaşları [20] tarafindan et köftelere tahıl kepeği eklenmesi sonucu $L$ değerlerinin ve $a$ değerlerinin değiştiği, kepek miktarı arttıkça $L$ değerinin arttığ değerinin ise düştüğü saptanmıştır. Başka bir çalışmada Kılınççeker [2] farklı gamlar ile hazırladığı tavuk köftelerin genel olarak renk değerlerinin iyileştiğini, sonuçlar üzerinde gam konsantrasyonlarının da etkili olduğunu bulmuştur. Ayrıca çalışmamıza yakın sonuçlar Lin ve Huang [21] ile Yılmaz ve Dağlıoğlu [22] tarafindan da gözlenerek, sonuçlarda ortaya çıkan farklılıklar çalışmalarda kullanılan malzemelerin doğal renk maddeleri ile ilişkilendirilmiştir.

Tablo 2. Gam türü ve konsantrasyonunun kızarmış sazan eti köftelerinin renk özellikleri üzerine etkileri

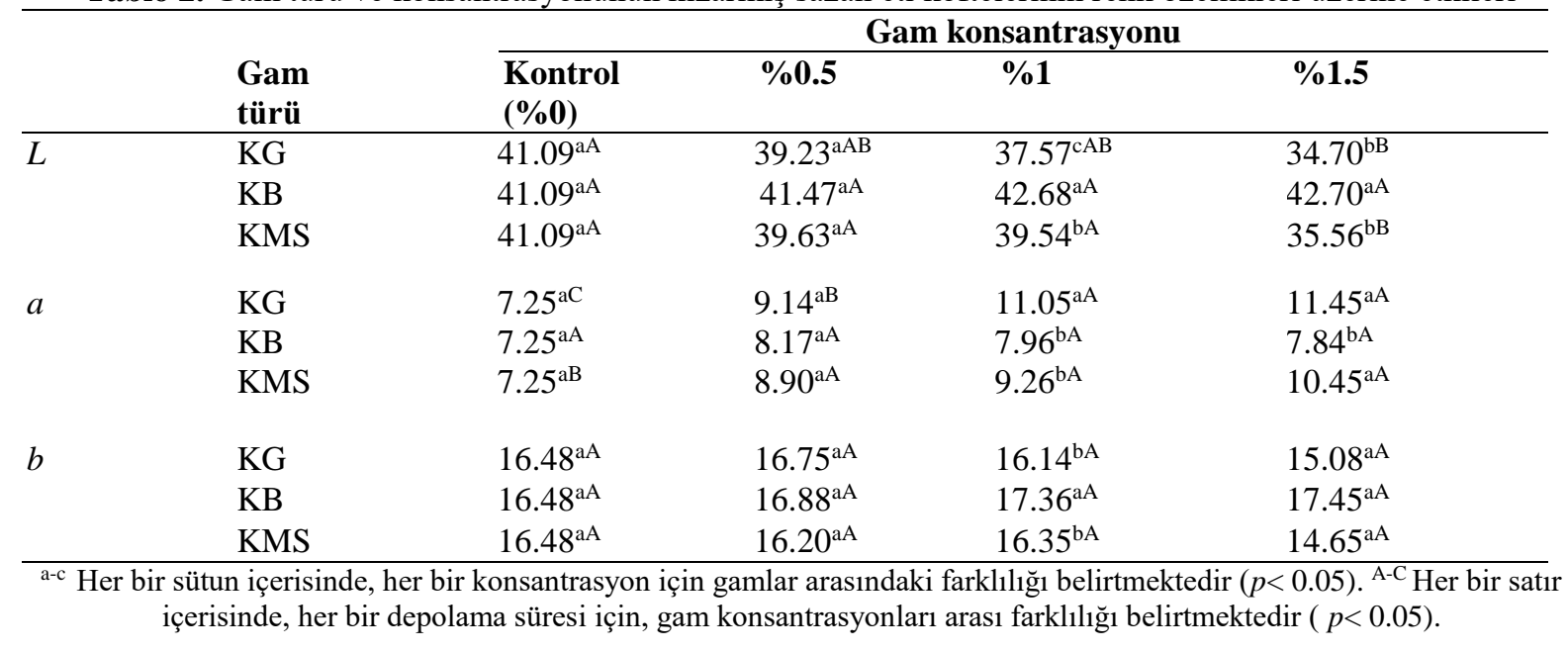

\subsection{Kızarmış sazan eti köftelerin bazı pişirme özellikleri}

Et ve su ürünlerinde kızartma sonrası değişim gösteren bazı pişirme özellikleri hem üretici hem de tüketici tercihini etkileyen önemli kriterlerdir. Bu özelliklerden pişirme sonrası elde edilen verim satılabilir ağırlığı etkilerken, çap değişimi paketleme ve depolamada üretici için önemli bir konudur. Ayrıca bu tarz ürünlerin nem ve yağ içerikleri kalori değerini etkilediğinden, sağlıklı beslenmeye çalışan tüketicinin ürüne olan talebini etkileyen hususlardır [5, 23, 24]. Çalışmada bu özelliklere ait sonuçlar Tablo 3'te sunulmuştur. Sonuçlara göre, gam türü kızartma verimi ve nem tutulumu için gamların bütün seviyelerinde önemli etkiye sahip olduğu, çap azalması için sadece $\% 1.5$ seviyesinde etkili olduğu anlaşılmaktadır $(p<0.05)$. Yağ emilim oranları üzerinde ise gam türlerinin bir etkisi olmadı̆̆ anlaşılmıştır ( $p>0.05$ ). Gam konsantrasyonu kızartma sonrası verimler üzerinde KG ve KB içerenlerde etkili olmuş, özellikle KB konsantrasyonu arttıkça verimde azalma, çapta ise düzensiz bir artış olduğu saptanmıştır. Tabloya göre KG nem tutulumunda daha avantajlı olarak bulunurken, diğer gamlar nem 
değerlerini düşürmüştür. Benzer şekilde, $K G$ artışı tutulan nemi artırırken, diğer gamların artması nemi düşürmüştür. Ayrıca, KB artışı emilen yağ oranını azaltmıştır. KG ve KMS gam içermeyen örneğe göre yağ oranlarını düşürseler de, $\% 0.5, \% 1$ ve $\% 1.5$ gam seviyelerinde farklılık sergilememişlerdir.

Tablo 3'ten de anlaşılacağı gibi en yüksek verim $\% 85.32$ ve $\% 86.18$ olarak $\% 1$ ve $\% 1.5 \mathrm{KG}$ ile hazırlanan ve kızartılan köftelerde saptanmıştır. En düşük çap azalması \%-4.99 ve \%-2.79 olarak \%1 ve $\% 1.5 \mathrm{~KB}$ içeren köftelerde ortaya çıkmıştır. Yani bu örneklerde çap artışı olmuştur. Kızartma sonrası nem tutma en yüksek $\% 77.78$ ve $\% 76.87$ olarak $\% 1$ ve $\% 1.5 \mathrm{KG}$ içeren köftelerde, en düşük yağ emilimi ise $\% 1.65$ olarak $\% 1.5 \mathrm{~KB}$ ile hazırlanan örneklerde tespit edilmiştir. Kızartma esnasında verim ve çap azalma oranları ısının etkisi ile protein denatürasyonundan olumsuz etkilenirken, çalışmada kullanılan gamların su tutma özellikleri ve jelatinize olma yetenekleri bu değerleri olumlu yönde etkilemiştir [2, 5]. Çalışmamıza benzer şekilde; Gibis ve arkadaşları [6] et köftelere eklenen \%0.5-3 oranındaki mikrokristali selülozun kızartma sonrası verimi artırdığını bulmuşlardır. Modi ve arkadaşları [3]'nın et köftelere KG ekleyerek yaptıkları başka bir çalışmada; gam eklemenin verimi artırdığı, çap küçülme oranlarını ise azalttığı belirlenmiştir. Ayrıca gamın ilave edilen miktarı arttıkça bu değerlerin daha da olumlu etkilendiği belirtilmiş, gamın su ile proteinlerin kompleks oluşturmasını kolaylaştırdığını ve madde kaybını azaltarak, şekli koruduğunu söylemişlerdir. Başka bir çalışmada et köftelere \%0-5 aralığında Aloe vera eklemenin pişirme verimini artırarak çap azalma oranlarını düşürdüğü belirlenmiştir. Eklenen Aloe vera miktarı arttıkça bu durumun desteklendiği, bu maddenin bir hidrokolloid gibi davranarak pişme süresince tutulan su miktarını artırdığı bulunmuştur [24]. Bizim çalışmamızdaki gamlar da benzer şekilde etki gösterirken, KB oranı artışı ile verimin azalması, artan sertlik sonucu daha kırılgan bir yapı oluşturması ve nem kaybının artmasına bağlanabilir. Benzer çalışmalarda; Pinero ve arkadaşları [25] sığır köftelerine \%13.45 oranında yulaf lifi eklemenin pişmiş örneklerde tutulan nem oranını artırdığını saptamışlardır. Sanchez-Zapata ve arkadaşları [26] domuz etinden yapılan köftelere ceviz lifi eklediklerinde nem tutma yeteneğinin arttığını gözlemlemişlerdir. Özellikle \%15 lif ilave etmenin $\% 5$ ve $\% 10$ oranlarından daha iyi sonuç ortaya çıkardığını vurgulamışlardır. Demirci ve arkadaşları [5] et köftelere katılan gamların nem kaybını azalttığını ve özellikle guar gamının etkili olduğunu saptamışlardır. Nem tutma ile ilgili; Ulu [1] ve Kılınççeker [2] tarafından yapılan çalışmalarda benzer sonuçlar bulunmuştur. Ayrıca, Mansour ve Khalil [23] et köfte içerisine buğday lifi eklemenin pişme sonrası örneklerdeki yağ oranını azalttığını saptamışlardır. Soltanizadeh ve Ghiasi-Esfehani [24] et köftelere ekledikleri \%5 oranındaki Aloe veranın kızartma esnasında tutulan nemi artırırken, emilen yağ oranını azalttığını belirlemişlerdir. Başka bir çalışmada ise Kılınççeker [2] tavuk köftelere $\% 0.5, \% 1$ ve \%1.5 oranında kattığı farklı gamlar ile kızartma esnasında emilen yağ oranının azaldığını ortaya çıkarmıştır. Bahsedilen çalışmalardaki nem tutma yăg emilim sonuçları bizim çalışmamızı desteklemektedirler.

Tablo 3. Gam türü ve konsantrasyonunun kızarmış sazan eti köftelerinin bazı pişirme özellikleri üzerine etkileri

\begin{tabular}{|c|c|c|c|c|c|}
\hline \multirow[b]{2}{*}{$\begin{array}{l}\text { Pişirme } \\
\text { özellikleri }\end{array}$} & \multirow[b]{2}{*}{$\begin{array}{c}\text { Gam } \\
\text { türüu }\end{array}$} & \multicolumn{4}{|c|}{ Gam konsantrasyonu } \\
\hline & & $\begin{array}{l}\text { Kontrol } \\
(\% 0)\end{array}$ & $\% 0.5$ & $\% 1$ & $\% 1.5$ \\
\hline \multirow{3}{*}{$\begin{array}{l}\text { K1zarma verimi } \\
(\%)\end{array}$} & $\mathrm{KG}$ & $77.44^{\mathrm{aB}}$ & $84.19^{\mathrm{aA}}$ & $85.32^{\mathrm{aA}}$ & $86.18^{\mathrm{aA}}$ \\
\hline & $\mathrm{KB}$ & $77.44^{\mathrm{aC}}$ & $82.48^{\mathrm{aA}}$ & $81.01^{\mathrm{bAB}}$ & $78.79^{\mathrm{bC}}$ \\
\hline & KMS & $77.44^{\mathrm{aA}}$ & $76.99^{\mathrm{bA}}$ & $76.40^{\mathrm{cA}}$ & $73.32^{\mathrm{cA}}$ \\
\hline \multirow[t]{3}{*}{ Çap azalması (\%) } & $\mathrm{KG}$ & $1.83^{\mathrm{aA}}$ & $0.31^{\mathrm{aA}}$ & $-0.57^{\mathrm{aA}}$ & $2.24^{\mathrm{aA}}$ \\
\hline & $\mathrm{KB}$ & $1.83^{\mathrm{aA}}$ & $-1.11^{\mathrm{aAB}}$ & $-4.99^{\mathrm{aB}}$ & $-2.79^{\mathrm{bAB}}$ \\
\hline & KMS & $1.83^{\mathrm{aA}}$ & $-2.16^{\mathrm{aA}}$ & $-2.32^{\mathrm{aA}}$ & $-1.69^{\mathrm{abA}}$ \\
\hline \multirow[t]{3}{*}{ Nem tutma $(\%)$} & $\mathrm{KG}$ & $66.56^{\mathrm{aB}}$ & $74.14^{\mathrm{aA}}$ & $77.78^{\mathrm{aA}}$ & $76.87^{\mathrm{aA}}$ \\
\hline & KB & $66.56^{\mathrm{aB}}$ & $73.13^{\mathrm{aA}}$ & $70.19^{\mathrm{bAB}}$ & $69.21^{\mathrm{bAB}}$ \\
\hline & KMS & $66.56^{\mathrm{aA}}$ & $65.06^{\mathrm{bAB}}$ & $64.77^{\mathrm{cAB}}$ & $61.10^{\mathrm{cB}}$ \\
\hline \multirow[t]{3}{*}{ Yağ emilimi (\%) } & $\mathrm{KG}$ & $3.33^{\mathrm{aA}}$ & $2.40^{\mathrm{aB}}$ & $2.12^{\mathrm{aB}}$ & $2.14^{\mathrm{aB}}$ \\
\hline & KB & $3.33^{\mathrm{aA}}$ & $1.96^{\mathrm{aB}}$ & $2.30^{\mathrm{aB}}$ & $1.65^{\mathrm{aC}}$ \\
\hline & KMS & $3.33^{\mathrm{aA}}$ & $2.37^{\mathrm{aB}}$ & $2.01^{\mathrm{aB}}$ & $2.18^{\mathrm{aB}}$ \\
\hline
\end{tabular}

${ }^{\mathrm{a}-\mathrm{c}}$ Her bir sütun içerisinde, her bir konsantrasyon için gamlar arasındaki farklılığı belirtmektedir $(p<0.05) .{ }^{\mathrm{A}-\mathrm{C}} \mathrm{Her}$ bir satır içerisinde, her bir depolama süresi için, gam konsantrasyonları arası farklılığı belirtmektedir $(p<0.05)$. 


\subsection{Kızarmış sazan eti köftelerinin duyusal özellikleri}

Duyusal kalite özellikleri son üründe kabul edilebilirliği gösteren önemli kalite faktörleridir. Özellikle yeni geliştirilen gıdalarda satış ve tüketim sırasında oluşan tüketici düşüncesini ortaya koyarlar. $\mathrm{Bu}$ nedenle son üründe mutlaka belirlenmesi gerekir $[2,13]$. Çalışmamız ile ilgili duyusal sonuçları Tablo 4'te verilmiş olup, bu tablodan gam türlerinin görünüş ve tat puanları üzerinde yalnızca $\% 1$ seviyelerinde etkili olduğu $(p<0.05)$, diğer özellikleri etkilemediği anlaşılmaktadır $(p>0.05) . \mathrm{Bu}$ kısımda özellikle KG ve KMS gamlarının avantaj1ı olduğu saptanmıştır. Gam konsantrasyonunun artışı ise görünüş, renk ve tat üzerinde etkiye sahip olmuştur. Özellikle KG artışı görünüş puanlarında düzensiz bir artışa sebep olurken, renk ve tat puanlarında düşüşe sebep olmuştur. Ancak genel olarak bu üç duyusal özellikte de kontrol örneği puanları gam içeren örneklerden daha düşük bulunmuştur. $\mathrm{Ne}$ gam türleri ne de gam konsantrasyonları koku ve tekstür puanları üzerinde herhangi bir etki göstermemişlerdir ( $p>0.05$ ). Tablo 4'e göre en yüksek görünüş puanlarının 6.65 ve 6.40 olarak, en yüksek renk ortalamalarının 7.11 ve 6.22 olarak $\% 0.5$ ve $\% 1 \mathrm{KG}$ ile hazırlanan köftelerde bulunduğu anlaşılmaktadır. En yüksek tat puanları ise 6.70 olarak \%0.5 KG ve 6.69 olarak \%1 KMS içeren örneklerde ortaya çıkmıştır. Bu sonuçlara göre; KG içeren köftelerin Tablo 2'de verilen renk değerlerinde de belirtildiği gibi kırmızılık değerlerinin ( $a$ değerleri) daha yüksek olması görünüşü etkilemiştir. Yine Tablo 2'den anlaşılacağı üzere konsantrasyon arttıkça parlaklığın ( $L$ değeri) azalması duyusal kriterlerden görünüş ve renk puanlarını düşürmüştür. Ayrıca, özellikle KG ile hazırlanan sazan eti köftelerde tutulan nem oranının yüksek olması tat puanlarında artışa sebep olmuştur. Çünkü puanlama esnasında panelistler tarafından da vurgulandığı gibi gam içeren sazan eti köftelerin kontrol örneğine göre daha sulu-çııır yapıda olması beğeni derecelerini artırmıştır. Çalışmamızdaki sonuçlar Kılınççeker [2]'in farklı gamlar ile hazırladığı tavuk köftelerin bazı duyusal özellik puanlarının kontrol örneğine göre arttığını belirttiği çalışma ile benzerlik göstermektedir. Ayrıca, Ibrahim ve arkadaşları [4]'nın maltodekstrin ve nişasta ile hazırladıkları tavuk köftelerde, Demirci ve arkadaşları [5]'nın gamlar ile hazırladıkları köftelerde de benzer sonuçlardan bahsedilmiştir. Bu çalışmalarda ürünlere hidrokolloid özellik sergileyen katkıları eklemenin duyusal özelliklerden bazılarını geliştirebildiği vurgulanmıştır.

Tablo 4. Gam türü ve konsantrasyonunun kızarmış sazan eti köftelerin duyusal özellikleri üzerine etkileri

\begin{tabular}{|c|c|c|c|c|c|}
\hline \multirow[b]{2}{*}{$\begin{array}{l}\text { Duyusal } \\
\text { özellikler }\end{array}$} & \multirow[b]{2}{*}{$\begin{array}{l}\text { Gam } \\
\text { türü }\end{array}$} & \multicolumn{4}{|c|}{ Gam konsantarsyonu } \\
\hline & & $\begin{array}{l}\text { Kontrol } \\
(\% 0)\end{array}$ & $\% 0.5$ & $\% 1$ & $\% 1.5$ \\
\hline \multirow[t]{3}{*}{ Görünüş } & KG & $5.26^{\mathrm{aB}}$ & $6.65^{\mathrm{aA}}$ & $6.40^{\mathrm{aAB}}$ & $5.59^{\mathrm{aAB}}$ \\
\hline & KB & $5.26^{\mathrm{aA}}$ & $5.18^{\mathrm{aA}}$ & $4.58^{\mathrm{bA}}$ & $4.92^{\mathrm{aA}}$ \\
\hline & KMS & $5.26^{\mathrm{aA}}$ & $5.19^{\mathrm{aA}}$ & $6.33^{\mathrm{aA}}$ & $5.05^{\mathrm{aA}}$ \\
\hline \multirow[t]{3}{*}{ Renk } & KG & $5.21^{\mathrm{aB}}$ & $7.11^{\mathrm{aA}}$ & $6.22^{\mathrm{aAB}}$ & $5.51^{\mathrm{aB}}$ \\
\hline & $\mathrm{KB}$ & $5.21^{\mathrm{aA}}$ & $5.00^{\mathrm{aA}}$ & $4.55^{\mathrm{aA}}$ & $5.02^{\mathrm{aA}}$ \\
\hline & KMS & $5.21^{\mathrm{aA}}$ & $5.23^{\mathrm{aA}}$ & $6.01^{\mathrm{aA}}$ & $4.81^{\mathrm{aA}}$ \\
\hline \multirow[t]{3}{*}{ Koku } & KG & $5.26^{\mathrm{aA}}$ & $6.53^{\mathrm{aA}}$ & $5.97^{\mathrm{aA}}$ & $5.62^{\mathrm{aA}}$ \\
\hline & $\mathrm{KB}$ & $5.26^{\mathrm{aA}}$ & $5.76^{\mathrm{aA}}$ & $4.87^{\mathrm{aA}}$ & $6.05^{\mathrm{aA}}$ \\
\hline & KMS & $5.26^{\mathrm{aA}}$ & $5.61^{\mathrm{aA}}$ & $6.40^{\mathrm{aA}}$ & $5.31^{\mathrm{aA}}$ \\
\hline \multirow[t]{3}{*}{ Tat } & KG & $5.59^{\mathrm{aB}}$ & $6.70^{\mathrm{aA}}$ & $6.29^{\mathrm{abA}}$ & $5.40^{\mathrm{aB}}$ \\
\hline & $\mathrm{KB}$ & $5.59^{\mathrm{aA}}$ & $5.25^{\mathrm{aA}}$ & $5.54^{\mathrm{bA}}$ & $5.29^{\mathrm{aA}}$ \\
\hline & KMS & $5.59^{\mathrm{aA}}$ & $6.24^{\mathrm{aA}}$ & $6.69^{\mathrm{aA}}$ & $4.90^{\mathrm{aA}}$ \\
\hline \multirow[t]{3}{*}{ Tekstür } & KG & $6.08^{\mathrm{aA}}$ & $6.07^{\mathrm{aA}}$ & $6.10^{\mathrm{aA}}$ & $5.44^{\mathrm{aA}}$ \\
\hline & KB & $6.08^{\mathrm{aA}}$ & $5.50^{\mathrm{aA}}$ & $5.44^{\mathrm{aA}}$ & $4.93^{\mathrm{aA}}$ \\
\hline & KMS & $6.08^{\mathrm{aA}}$ & $5.31^{\mathrm{aA}}$ & $6.45^{\mathrm{aA}}$ & $5.04^{\mathrm{aA}}$ \\
\hline
\end{tabular}

\footnotetext{
${ }^{\text {a-b }}$ Her bir sütun içerisinde, her bir konsantrasyon için gamlar arasındaki farklılı̆̆ 1 belirtmektedir $(p<0.05) .{ }^{\text {A-B }}$ Her bir satır içerisinde, her bir depolama süresi için, gam konsantrasyonları arası farklılığı belirtmektedir $(p<0.05)$.
} 


\section{Sonuç}

Yapılan bu çalışma ile sazan (Cyprinus carpio L.) eti köftelerine gam katmanın ürünün bazı özelliklerini olumlu yönde etkileyebileceği anlaşılmıştır. Hazırlanan pişmemiş sazan eti köftelerin soğukta depolanması esnasında $\mathrm{pH}$ ve TBARS değerlerindeki ilerlemenin azaltılabileceği anlaş11ırken, renk değerlerinin ise çok fazla etkilenmeyeceği gözlenmiştir. Hatta depolama ile renk değerlerinde azalmalar olabileceği anlaşılmıştır. Buna karşın gam ilavesi ile kızartılan sazan eti köftelerinde renk değerleri olumlu yönde geliştirilirken, kızartma sonrası verim, nem oranı ve duyusal özelliklerin artırılabileceği, yağ emiliminin ise azaltılabileceği gözlenmiştir. Çalışma sonunda, elde edilen bütün sonuçlara bağlı olarak sazan etinden köfte yapımında özellikle \%1 karagenan veya \%1.5 keçi boynuzu gamlarını eklemenin diğer muamelelere kıyasla daha avantajlı oldukları ortaya çıkarılmıştır.

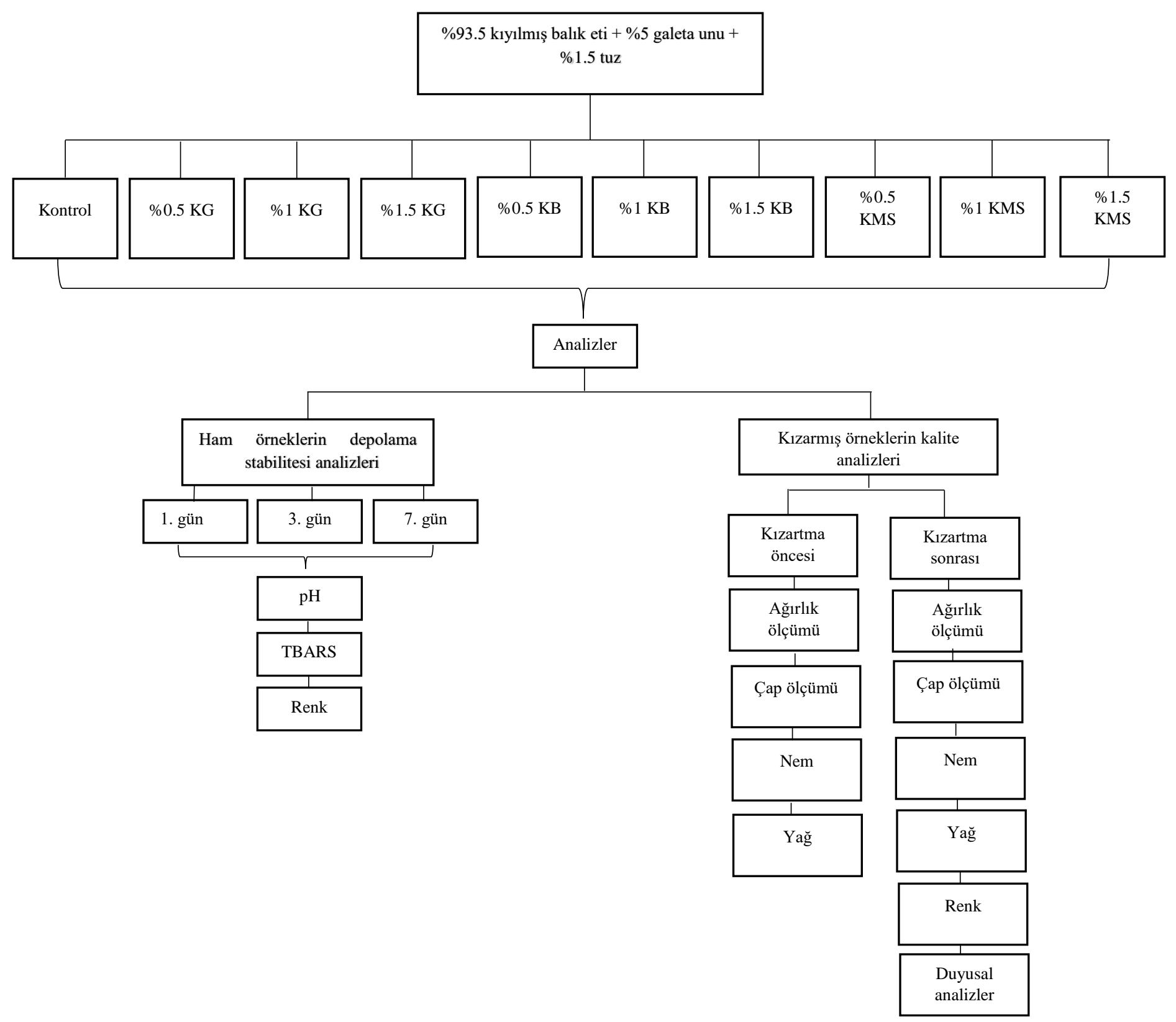

Şekil 1. Çalışma akış diyagramı 


\section{Kaynaklar}

[1] Ulu H. 2006. Effects of Carrageenan and Guar Gum on the Cooking and Textural Properties of Low Fat Meatballs, Food Chemistry, 95 (4): 600-605.

[2] Kılınççeker O. 2017. Tara, Tragakant ve Agar Agar Gamlarının Tavuk Köftelerde Kullanımı. Gıda, 42 (3): 219-228.

[3] Modi V.K., Yashoda K.P., Naveen S.K. 2009. Effect of Carrageenan and Oat Flour on Quality Characteristics of Meat Kofta, International Journal of Food Properties, 12 (1): 228-242.

[4] Ibrahim M.A., Salama M.F., Hussein A.A. 2011. Production of Low-Fat Chicken Burger, Australian Journal of Basic and Applied Science, 5 (12): 3149-3154.

[5] Demirci Z.O., Y1lmaz I., Demirci A.Ş. 2014 Effects of Xanthan, Guar, Carrageenan, and Locust Bean Gum Addition on Physical, Chemical, and Sensory Properties of Meatballs, Journal of Food Sciences and Technology, 51 (1): 936-942.

[6] Gibis M., Schuh V., Weiss J. 2015. Effects of Carboxymethyl Cellulose (CMC) and Microcrystalline Cellulose (MCC) as Fat Replacers on the Microstructure and Sensory Characteristics of Fried Beef Patties, Food Hydrocoloids, 45 (2): 236-246.

[7] Sanz T., Salvador A., Fiszman S.M. 2004. Effect of Concentration and Temperature on Properties of Methylcellulose-Added Batters Application to Battered Fried Seafood, Food Hydrocolloids, 18 (1): 127-131.

[8] Kilincceker O., Dogan I.S., Kucukoner E. 2009. Effect of Edible Coatings on the Quality of Frozen Fish Fillets, LWT- Food Science and Technology, 42 (4): 868-873.

[9] Ockerman, H.W. 1985. pH measurement. In: Quality Control of Post Mortem Muscle Tissue ( $2^{\text {nd }}$ ed.). The Ohio State University, Columbus Ohio.

[10] Tarladgis B.G., Watts B.M., Younathan M.T. 1960. A Distillation Method for the Quantitative Determination of Malonaldehyde in Rancid Foods, Journal of American Oil Chemistry Society, 37 (1): 44-48.

[11] AOAC. 2002. Offical methods of analysis (17 ${ }^{\text {th }}$ ed.). Association of Official Analytical Chemists, Washington, DC.

[12] Varlık C., Uğur M., Gökoğlu N., Gün H. 1993. Su Ürünlerinde Kalite Kontrol İlke ve Yöntemleri. Gıda Tek. Derneği Yayınları, Yayın No: 17, İstanbul.

[13] Gökalp H.Y., Kaya M., Tülek Y., Zorba Ö. 1999. Et ve Ürünlerinde Kalite Kontrolü ve Laboratuvar Uygulama Klavuzu. (Üçüncü Baskı), Atatürk Üniv. Yay. Yay No: 318, Erzurum.

[14] K1lınççeker O. 2015. Some Quality Caharacteristics of Fish Meatballs Manufactured with Different Vegetable-Based Flours, Gida, 4 (2): 61-67.

[15] K1lınççeker O., Hepsağ F., Kurt S. 2015. The Effects of Lentil and Chickpea Flours as the Breading Materials on Some Properties of Chicken Meatballs During Frozen Storage, Journal of Food Sciences and Technology, 52 (1): 580-585.

[16] Cadun A., Çaklı Ş., Kışla D., Dinçer T., Erdem Ö.A. 2015. Effects of Fibers on the Quality of Fish Patties Stored at $\left(0-4{ }^{\circ} \mathrm{C}\right)$, Journal of Food and Health Sciences, 1 (4): 211-219.

[17] Gülyavuz H., Ünlüsayın M. 1999. Su Ürünleri İşleme Teknolojisi. Ders kitabı. Şahin Matbaası, Ankara.

[18] Göğüş A.K., Kolsarıcı N. 1992. Su Ürünleri Teknolojisi, Ankara Üniv. Zir. Fak. Yay. No: 358, Ankara. 1992.

[19] Cava R, Ladero-Cantero L, Ramirez V.R. 2012. Assessment of Different Dietary Fibers (tomato fiber, beet root fiber, and inulin) for the Manufacture of Chopped Cooked Chicken Products, Journal of Food Sciences, 77 (4): 346-352.

[20] Yasarlar E.E., Dağlıŏglu O., Y1lmaz I. 2007. Effects of Cereal Bran Addition on Chemical Composition, Cooking Characteristics and Sensory Properties of Turkish Meatballs, Asian Journal of Chemistry, 19 (3): 2353-2361.

[21] Lin K.W., Huang H.Y. 2003. Konjac/gellan Gum Mixed Gels Improve the Quality of Reduced Fat Frankfurters, Meat Sciences, 65 (2): 749-755.

[22] Yılmaz I., Dağlığlu O. 2003. The effect of Replacing Fat with Oat Bran on Fatty Acid Composition and Physicochemical Properties of Meatballs, Meat Sciences, 65 (2): 819-823.

[23] Mansour E.H., Khalil A.H. 1997. Characteristics of Low-fat Beef Burger as Influenced by Various Types of Wheat Fibers, Food Research International, 30 (3-4): 199-205. 
[24] Soltanizadeh N., Ghiasi-Esfahani H. 2015. Qualitative Improvement of Low Meat Beef Burger Using Aloe vera, Meat Science, 99 (1): 75-80.

[25] Pinero M.P., Parra K., Huerta-Leidenz N., Moreno L.A., Ferrer M., Araujo S., Barboza Y. 2008. Effect of Oat's Soluble ( $\beta$-glucan) as a Fat Replacer on Physical, Chemical, Microbiological and Sensory Properties of Low-fat Beef Patties, Meat Sciences, 80 (3): 675-680.

[26] Sanchez-Zapata E., Munoz C.M., Fuentes E., Fernandez-Lopez J., Sendra A., Sayas E.E., Navarro C. 2010. Effect of Tiger Nut Fiber on Quality Characteristics of Pork Burger, Meat Sciences, 85 (1): 70-76. 